Open access e-Journal

Earth Science India, eISSN: $0974-8350$

Vol. 8 (II), April, 2015, pp. 32-49

http://www.earthscienceindia.info/

\title{
GEO-ENVIRONMENTAL ASSESSMENT OF LONI NALA SUB-UNIT, GOMATI BASIN, INDIA, USING GIS TECHNIQUE
}

\author{
Archana Gupta ${ }^{1}$, Biswajeet Thakur ${ }^{2}$, Akanksha Shukla ${ }^{1}$ and Dhruv Sen Singh ${ }^{3}$ \\ ${ }^{1}$ Department of Geography, University of Lucknow, Lucknow-226007 \\ ${ }^{2}$ Birbal Sahni Institute of Palaeobotany, Lucknow-226007 \\ ${ }^{3}$ Centre of Advanced Study in Geology, University of Lucknow, Lucknow-226007
}

\begin{abstract}
Geo-environmental assessment of any fluvial basin plays a major role in defining the structure of that basin in terms of geomophology, morphometry, land use practices etc. In the present paper, geo-environmental assessment has been carried out in Loni Nala sub-unit of Gomati basin using remote sensing and GIS techniques for demarcating the natural as well as tectonic element of fluvial morphology. Further, it has also been discussed how the surface analysis (geomorphology, morphometry, land use, DEM and contour) play important role in deciphering the suitablity of this sub-unit for prospect in water recharge and agricultural sustainability with growing concretization.
\end{abstract}

Keywords: Loni Nala sub-unit; geomorphology; morphometry; tectonic; fluvial morphology; remote sensing; GIS.

\section{Introduction}

The Ganga Plain exhibits a very low relief and gentle regional slope towards SE to E direction, where the northern part shows southward slope and southern part shows northward slope. The earlier workers like Oldham (1917); Pascoe (1917); Pilgrim (1919); Geddes (1960); Mukherji (1963) and Das Gupta (1975) classified two major morphostratigraphic units namely, the Newer Alluvium (Khadar) and the Older Alluvium (Bhangar). It is viewed that the Older Alluvium makes the higher interfluve areas, while the Newer Alluvium forms deposits of the minor river channels and their valleys. The Bhangar surface is a depositional terrace of Pleistocene age and emphasized the role of changing climate and sea level during Pleistocene-Holocene times (Mukherji, 1963). It is well established that the present geomorphology of the Ganga Plain is a result of complex interaction between climate change associated with base level change and tectonic activity during Late Pleistocene-Holocene (Srivastava et al., 2003). In general, the Ganga Plain is divided from north to south into three broad units, namely, Piedmont Plain, Central Alluvial Plain and Marginal Alluvial Plain (Singh, 1996; Singh, 2001).

The Ganga Plain exhibits a variety of landforms on varying scale, which have formed during Quaternary. It is an active peripheral foreland basin (Singh, 1996) under which the crust is flexed down by load of the Himalaya. The still active Himalaya, due to its proximity to the Ganga Plain influences the nature of the sediment fill, geomorphic features and fluvial processes. The neotectonic activities of the Ganga Plain have been recorded by a number of workers namely, Singh and Rastogi (1973); Singh and Bajpai (1989); Mohindra et al. (1992); Mohindra and Parkash (1994); Singh and Ghosh (1994); Srivastava et al. (1994); Misra et al. (1994); Kumar et al. (1996); Singh (1996, 1999, 2001); Singh et al. (1996); Parkash et al. (2000) and Agarwal et al. (2002). 
The Ganga Plain is one of the largest terrestrial basins of the world, which is continuously affected by compressional forces related to Himalayan orogeny. Various geological forces such as tectonics and base level changes associated with climatic perturbations have resulted into the formation of diverse geomorphic features such as rivers, ponds, lakes and geomorphic surfaces of the Ganga Plain. With the advent of remote sensing technology, the identification of various geomorphic characteristics of the Ganga Plain has become easy as well as versatile with multi-facet studies. Using IRS remote sensing satellite imageries and 1:50,000 scale topographic maps Sinha et al., (2005) have distinguished seven mega-geomorphic units of the Ganga Plain.

The importance of the Ganga Plain is owed by its importance in unraveling the various aspects of tectonics and climate variations in geomorphology. The Gomati Basin is one of the promising basins in Ganga Plain which shows salient features of tectonics through its drainage system by the representation of morphometric analysis, DEM and geomorphic evidences. In the present study, a small but important sub-unit of Gomati River i.e. Loni Nala drainage system has been investigated for its geo-environmental appraisal.

\section{Study Area}

The Gomati River is a groundwater fed tributary of the Ganga River. It originates near the Madho Tanda in Pilibhit district of Uttar Pradesh. The place of origin is located near Himalayan foothill zone in the Piedmont Zone of the Ganga Plain. It covers a distance of 900 km before meeting the Ganga River in Ghazipur district, Uttar Pradesh. During its course the river flows through the districts of Pilibhit, Shahjahanpur, Sitapur, Lucknow, Barabanki, Sultanpur, Jaunpur and Ghazipur in Uttar Pradesh. The Gomati River forms an elongate basin, trending in NW-SE direction. It is a gently sloping drainage basin with a total area of $30,437 \mathrm{~km}^{2}$. In the present study, the Loni Nala sub-unit of the Gomati River, in the GangaGhaghara interfluve region, has been investigated (Fig. 1).

\section{Materials and Methods}

In the present study remote sensing and GIS applications are used in conjunction to provide valuable geo-environmental assessment of the Loni Nala basin. The drainage basin characteristics were delineated using ArcView 3.2 software from Survey of India (SOI) topographic maps on 1:50,000 scale and SRTM data (90 m resolution). The geomorphology and land use/ land cover maps were prepared using ETM $+(15-30 \mathrm{~m}$ resolution) data downloaded from open access site (http://glcfapp.glcf.umd.edu:8080/esdi/) and the digital elevation model (DEM) and contour map was prepared from SRTM data (http://srtm.csi.cgiar.org/). The initial data viz. drainage basin, perimeter, basin length, and water divide were measured and delineated using GIS from SOI topographic maps. The stage of landscape evolution, tilting of the basin, stream power of denudation and migration of the Loni Nala were determined by the morphometric analysis. The drainage network was analyzed according to Horton's laws (Horton, 1945) and stream orders were defined (Strahler, 1964). Various basic, derived, and shape parameters were calculated using standard methods (Kale and Gupta, 2001; Reddy et al. 2004; Sreedevi et al. 2005; Garde, 2006; Awasthi and Singh, 2011; Vandana, 2013). 
Open access e-Journal

Earth Science India, eISSN: $0974-8350$

Vol. 8 (II), April, 2015, pp. 32-49

http://www.earthscienceindia.info/

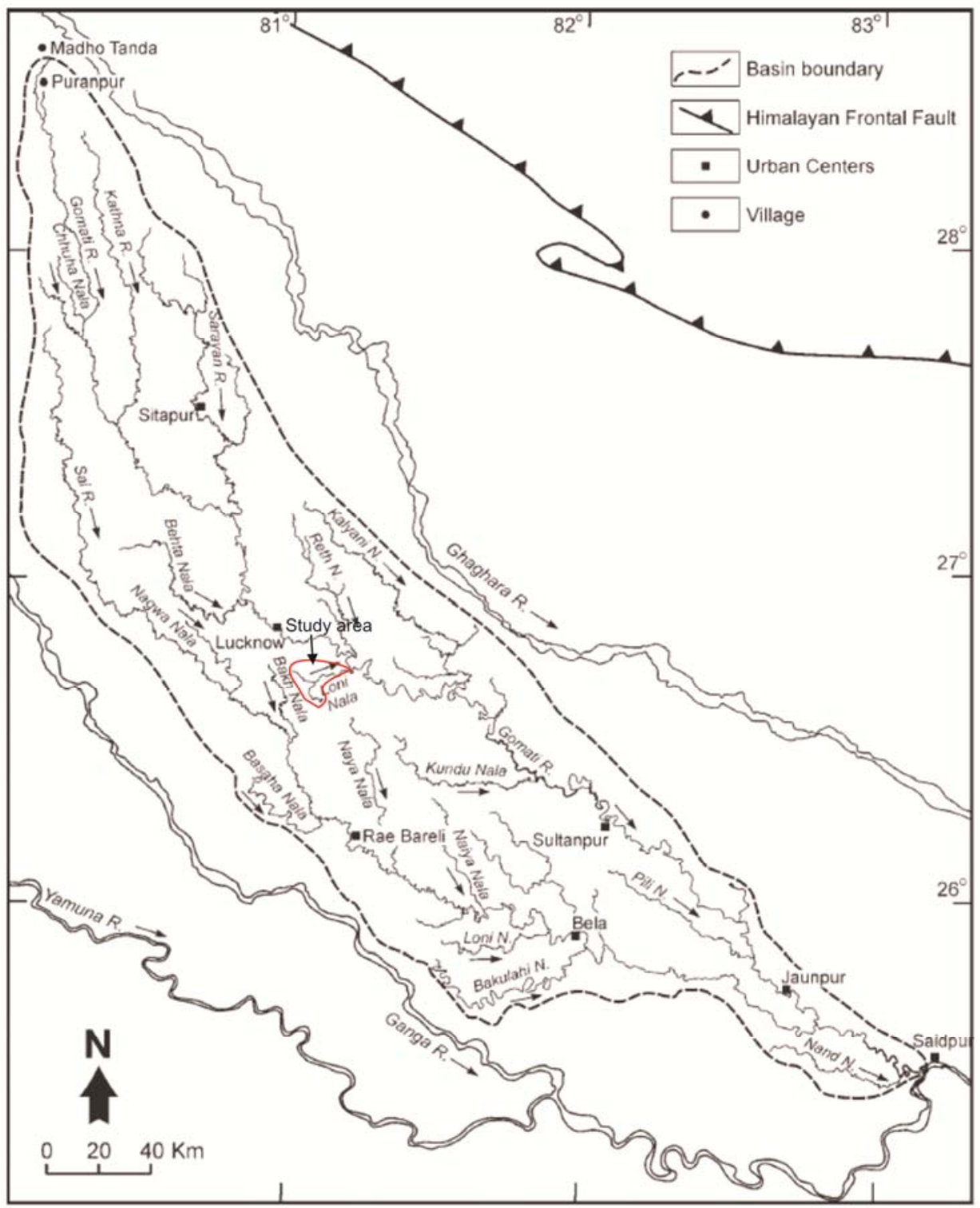

Fig. 1: The Gomati River and its tributaries in the interfluves region of the Ganga and Ghaghara rivers along with Loni Nala basin (after Thakur, 2007).

\section{Results and Discussions}

\section{Morphometric analysis}

The morphometric parameters were calculated under three different categories: (i) basic parameters, (ii) derived parameters, and (iii) shape parameters, which provide information regarding the river and its basin characteristics (Fig. 2; Table-1). 
Table- 1: Morphometric parameters of Loni River Basin

\begin{tabular}{|c|c|c|c|c|c|}
\hline \multicolumn{2}{|l|}{ Basic Parameters } & \multicolumn{2}{|c|}{ Derived Parameters } & \multicolumn{2}{|c|}{$\begin{array}{l}\text { Shape } \\
\text { Parameters }\end{array}$} \\
\hline Area (A) (km2) & 97.3 & & & & \\
\hline Perimeter (P) (km) & 45.7 & & & & \\
\hline $\begin{array}{l}\text { Basin length (L) } \\
(\mathrm{km})\end{array}$ & 17.2 & & & & \\
\hline N1 & 77 & $\mathrm{Rb} 1$ & 7 & $\operatorname{Re}$ & 0.65 \\
\hline N2 & 11 & $\mathrm{Rb} 2$ & 11 & Rc & 0.60 \\
\hline N3 & 1 & $\mathbf{R b}$ & 6 & $\mathrm{E}$ & 2.40 \\
\hline Total (Nu) & 89 & & & & \\
\hline L1 (km) & 51.8 & Rl 2-1 & 3.4 & & \\
\hline L2 (km) & 26.7 & Rl 3-2 & 9.4 & & \\
\hline L3 (km) & 22.6 & RI & 6.4 & & \\
\hline Total (Lu) & 101.1 & RHO & 0.711 & & \\
\hline Max. height $(\mathrm{H})$ & 119 & Fs $\left(\mathrm{km}^{-2}\right)$ & 0.91 & & \\
\hline Min. Height (h) & 109 & $\mathrm{Dd}\left(\mathrm{km}^{-1}\right)$ & 1.04 & & \\
\hline $\mathrm{Sb}\left(\mathrm{m} \mathrm{km}^{-1}\right)$ & 0.30 & $\mathrm{~T}\left(\mathrm{~km}^{-1}\right)$ & 0.94 & & \\
\hline & & $\mathrm{R}(\mathrm{m})$ & 10 & & \\
\hline & & $\mathrm{Rr}$ & 0.58 & & \\
\hline & & $\mathrm{Ff}$ & 0.33 & & \\
\hline
\end{tabular}

Basic, Derived and Shape parameters of Loni Nala River: Area(A), perimeter (P), Basin length (L), Stream order (Nu), Stream length (Lu), Slope (Sb), Basin relief (R), Relief ratio (Rr), Bifurcation ratio (Rb), Stream length ratio (Rl), RHO coefficient (RHO), Stream frequency (Fs), Drainage density (Dd), Drainage texture ( $\mathrm{T}$ ), Elongation ratio (Re), Circularity index (Rc), Maximum height(H), Minimum height(h), Elipticity Index (E), Form factor $(\mathrm{Ff})$.

\section{Basic Parameters}

Stream order $(\mathbf{N u})$ : It is defined on the basis of number and type of tributary junctions. It is useful indicator of stream size, discharge, and drainage area (Strahler, 1964). Total stream number $(\mathrm{N})$ of each stream order $(\mathrm{u})$ is given in Table-1. Stream parameters verify Horton's first law (stream number) which envisages that a simple geometric relationship exists between the order of the stream on one hand and the number, average length, channel slope and average basin area of each order on the other. The relationship show that for streams of increasing order the average length and average drainage area of streams of each order increases, but the number and channel gradient decreases. The inverse geometric relationship is displayed as a straight line when 'log $\mathrm{Nu}$ ' is plotted against stream order (Nu) (Fig. 2B). The number of first order streams (77) indicates mature stage of topography. In the mature stage, river widens its valley. The average bifurcation ratio is greater than 5 indicating structural control of the drainages.

Stream length ( $\mathbf{L u})$ : Stream length is measured for different order of streams (Table-1). The stream length $(\mathrm{Lu})$ of particular order $(\mathrm{u})$ and total stream length $(\mathrm{Lt})$ of the basin confirm Horton's second law, (law of stream length). It says that average length of stream of each different order in a drainage basin tends closely to approximate a direct geometric series in which the first term is average length of streams of the first order. The cumulative mean 
Open access e-Journal

Earth Science India, eISSN: $0974-8350$

Vol. 8 (II), April, 2015, pp. 32-49

http://www.earthscienceindia.info/

lengths of stream segments of successively higher order tend to form a geometric progression beginning with the cumulative mean length of the first order segments and increasing according to a constant length ratio. Log values of stream length $(\mathrm{Lu})$ and stream order $(\mathrm{Nu})$ plotted on a graph shows geometric linear relationship (Fig. 2C).

Slope (Sb): Slope is a morphometric parameter of hydrological relevance. Steep slopes generally have high surface run-off, high sediment production, and low infiltration rate. Gentle slope gradient of this basin $(0.30 \mathrm{~m} \mathrm{~km}-1)$ indicate, low surface run-off, low sediment production, and high infiltration rate.

Derived Parameters: These parameters are generated from basic parameters such as, basin relief $(\mathrm{R})$, relief-ratio $(\mathrm{Rr})$, bifurcation ratio $(\mathrm{Rb})$, stream-length ratio $(\mathrm{Rl})$, RHO coefficient (RHO), stream frequency (Fs), drainage density (Dd) and drainage texture (T).

Basin Relief (R): Basin relief is the difference in elevation between the highest and lowest point of the basin. It determines the slope and so the run-off and sediment transport. Low value of basin relief $(10 \mathrm{~m})$ indicates low run-off, low sediment transport, and spreading of water within the basin.

Relief-Ratio ( $\boldsymbol{R r})$ : Relief-ratio $(R r)$ is a dimensionless parameter. It is the ratio between basin relief $(R)$ and basin length $(L)$ (Schumm, 1963) and is directly proportional to the surface runoff and intensity of erosion. It is 0.58 for this basin and indicates low to medium surface runoff, and low stream power for erosion.

Bifurcation Ratio (Rb): It is the ratio between number of streams of any given order (Nu) to the number of streams in the next higher order $(\mathrm{Nu}+1)$ (Horton, 1945) and reflects the degree of ramification of drainage network. Bifurcation ratio varies from 3-5 for natural drainage system. It is 6 for this basin, which falls above the normal range (3-5). It shows that the drainages are influenced by structural setup.

Stream-length Ratio (RI): Stream length ratio $(R l)$ isdefined as: Where, $\mathrm{Lu}$ is the stream length of order ' $u$ ' and Lu-1 is stream segment length of the next lower order. It varies due to difference in slope and topographic condition, between successive stream orders and has an important relationship with the surface flow and erosional stage of the basin (Sreedevi et al., 2005). The average Rl value (6.4) for this basin shows mature stage of erosion and low surface run off.

RHO Coefficient (RHO): It is the ratio of $R l$ (stream length ratio) and $R b$ (bifurcation ratio) and represents relationship between drainage density and physiographic development of the basin (Horton, 1945). It is considered to be an important parameter as it determines the relationship between the drainage density and the physiographic development of the basin and allows the evaluation of the storage capacity of the drainage network (Horton 1945). The RHO coefficient of Loni Nala is 0.71 which is at higher side and thus indicates higher water storage during flood periods and attenuates the erosion effect during elevated discharge (Mesa, 2006). 
Stream Frequency (Fs): Stream frequency (Fs) is defined as the ratio between total number of stream segment of all orders in a basin and the basin area. It is measure of the permeability of surface lithology, vegetation, and relief. It is $0.91 \mathrm{~km}^{-2}$ for this basin which indicate highly permeable alluvium and low relief.

Drainage Density (Dd): Drainage density $(D d)$ is the total length of stream per unit area of drainage basin. Low value of ' $D d$ ' indicates highly permeable region (Horton, 1945). It is 1.04 for this basin and reflects highly permeable and easily erodible alluvium. It is mainly influenced by the resistance of the bed material to erosion, and capacity of infiltration.

Drainage Texture (T): It is the relative channel spacing in a fluvial dissected terrain and depends upon a number of natural factors such as climate, rainfall, vegetation, rock/ soil type, rate of infiltration, relief and evolutionary stage of the basin (Kale and Gupta, 2001). It is calculated by multiplying drainage density with stream frequency. The drainage texture $(T)$ is coarse, intermediate, fine, and ultra fine (badland topography) if the values are $<4,4-10$, $>$ 10 , and $>15$ respectively (Smith, 1950). Very coarse drainage texture $(T=0.94)$ for this basin indicates that the channels are far away from each other.

Form Factor (Ff): Form Factor (Ff) is defined as the ratio of the basin area to the square of the basin length. It is 0.33 for this basin.

Shape Parameters: Shape parameters such as elongation ratio $(R e)$, circularity index $(R c)$ and indicate shape characteristics of the basin (Table-1).

Elongation Ratio (Re): Elongation ratio $(\mathrm{Re})$ is defined as the ratio between the diameter of a circle of the same area as that of the basin $(D)$ and basin length $(L)$. The elongation ratio $(R e)$ value 0.65 indicates the semi-circular shape of the basin.

Circularity Index (Rc): The Circularity index (Rc) is expressed as the ratio of basin area $(A)$ and area of a circle with the same perimeter as that of the basin $(P)$. Where, Rc is the basin circularity, $\mathrm{P}$ is basin perimeter, $\mathrm{A}$ is area of the basin and 4 is a constant. Unit circularity index (Rc) shows circular shape of basin and indicate uniform infiltration with long time for surplus water to reach the outlet or confluence which further depends on geology, slope, and land cover (Reddy et al., 2004). The Circularity index (Rc) value (0.60) indicates semicircular shape and mature topography.

Ellipticity Index (E): It indicates the elliptical shape of any basin. In the present case the E (2.40) represent small value indication more towards circularity rather than ellipticity.

\section{Geomorphology}

Loni Nala, the tributary of Gomati River, is a groundwater fed river and represents unique depositional system of fluvial environment. The catchment falls under fluvial plain of Loni Nala, and display discernible geomorphic features such as, older alluvial plain, younger alluvial plain, active flood plain, old meander and palaeo-channels (Fig. 4). A brief description of each is given below:

a) Flood Plain: Flood plain is an area with alluvial soils, adjacent to streams, which is flooded by stream water on periodic basis. It appears as a narrow strip of land alongside the river. So, the low lying areas on both sides of river beyond the natural levees are, invariably 
Open access e-Journal

Earth Science India, eISSN: $0974-8350$

Vol. 8 (II), April, 2015, pp. 32-49

http://www.earthscienceindia.info/

subjected to periodical flooding. Brown to light olive brown, very deep, fine loamy, imperfect to poorly drain aquic soils have been developed in such areas.

b) Younger Alluvial Plain ( $\left.\mathbf{T}_{\mathbf{1}}\right)$ : It is the former flood plain of a stream. Relatively smooth, flat to gently sloping and slightly undulating surface characterized by deposits of unconsolidated alluvial material deposited by river. It comprises sand, silt and clay sequences of late cycle of fluvial deposits. The younger alluvial plains are represented by river terraces $\left(\mathrm{T}_{1}\right)$ which are at higher level (105-115 $\mathrm{m}$ above msl) than the flood plains. A district slope break, bordering younger alluvial plain separates at from both flood plain (at lower level) and older alluvial plain (at higher level).

c) Older Alluvial Plain ( $\left.\mathbf{T}_{2}\right)$ : Relatively smooth, flat to gently sloping and slightly undulating terrain characterized by extensive deposits of unconsolidated material deposited by rivers. The older alluvium can be further subdivided as paleo-terrace alluvium. It is more extensive and has polycyclic multiple sequence of grey sand (Khaki) to yellow silt and clay with intermittent calcareous horizons. It is composed of oxidized, brown, highly micaceous sand of fine to medium grain. The sand unit has been recognized as "Bhur" deposits.

d) Old meander: These are meander loops which are cutoff from the main stream and in the present there is no water present. Presently, these old meanders have been converted into either agricultural land or concretization due to heavy land acquisition.

e) Palaeo-channel: These are remnant of an inactive river or stream channel that has been either filled or buried by younger sediment. The sediments that the ancient channel is either cut into or buried by can be unconsolidated, semi-consolidated, consolidated, or lithified. A well demarcated palaeo-channel can be seen near Hasanpur and is projected in NE-SW direction. The palaeo-channel is differently oriented from the present active channel.

\section{Land-use/ Land cover}

The land use of the Loni sub-watershed shows that it is predominantly agricultural particularly double cropped area and sometimes it also has area which characterises with more than two crops which clearly points out that the soil of study area is very fertile in nature. The area under agricultural activities is 13735.23 hectare which is 75 per cent of total area. A considerable feature is that the land under current fallow is 9 per cent and while the land under horticulture is 0.79 per cent. The area in the sub-watershed is largely covered by major crops grown in kharif and rabi seasons. Wheat, Paddy, Maize, Urad, Pigeonpea, Jowar, Bajra, Potato, Sunflower, roses, and marigold are also cultivated in large area. The subwatershed is one of the major producers of wheat and paddy. It is also a main producer of potato. Medicinal and aromatic plant cultivation, mushroom cultivation has been taken up as innovative activities by some entrepreneurs in the area.

The study also observed a considerable part of sub-watershed is under waste lands. Wastelands are such degraded lands which can be brought under vegetative cover, with reasonable effort, and which are currently under-utilized, and lands which are deteriorating due to lack of appropriate water and soil management or on account of natural causes. The clear and well defined large patches of sodic lands are also delineated which are clustered 
around the canal system. Around 9.45 percent area is under sodic land which needs proper reclamation (Table-2; Fig. 3 and 5).

Table- 2: Land use/ land cover data of Loni Nala, Gomati basin

\begin{tabular}{|c|c|c|}
\hline S.No. & Land Use /Cover & Area(Hectare) \\
\hline 1 & Built Up Area ( Rural) & 132.0017 \\
\hline 2 & Agricultural Land-Crop Land-Kharif & 3676.456 \\
\hline 3 & Agricultural Land-Crop Land-Rabi & 710.3278 \\
\hline 4 & $\begin{array}{l}\text { Agriculture Land -Crop Land- Two } \\
\text { Crop Area }\end{array}$ & 9275.7132 \\
\hline 5 & $\begin{array}{l}\text { Agriculture Land -Crop Land-More } \\
\text { than Two Crop }\end{array}$ & 72.7341 \\
\hline 6 & $\begin{array}{l}\text { Agricultural Land-Fallow- Current } \\
\text { fallow }\end{array}$ & 1592.575 \\
\hline 7 & $\begin{array}{l}\text { Agricultural } \\
\text { Horticulture Plant Land-Plantation- }\end{array}$ & 144.9184 \\
\hline 8 & Wasteland Sodic Land-Slight & 242.1412 \\
\hline 9 & Wasteland Sodic Land-Moderate & 1487.021 \\
\hline 10 & Wasteland-Gullied land & 8.2518 \\
\hline 11 & Wasteland-Scrub Land-Dense & 204.993 \\
\hline 12 & Wasteland-Scrub Land-Open & 58.9791 \\
\hline 13 & Wetlands-Inland-Natural & 440.3837 \\
\hline 14 & Waterbodies-River-Perennial & 37.937 \\
\hline 15 & Waterbodies-Canal-Lined & 210.4608 \\
\hline
\end{tabular}

\section{Digital Elevation Model (DEM)}

The elevation profile of the DEM ranges between 98 to $128 \mathrm{~m}$ in the sub-watershed (Fig. 6). The colour variation of the DEM indicates the varying topographical signature that accumulates the information regarding the slope and distance constraints. The low relief and elevation can be well observed in the DEM. The change in elevation from NW to SE can be easily visualized. This corroborates with the direction of the Ganga Plain which also lowers in elevation from NW to SE direction in the basinal setup.

\section{Contour map}

The contour map of the Loni Nala shows that contour variation from 100 to $128 \mathrm{~m}$ (Fig. 7). The contour interval in the present study has been demarcated for every $2 \mathrm{~m}$ interval. The contours show that away from the channels they are well separated and bounded. This may be due to the low relief and slope characteristics due to $\mathrm{T}_{2}$-surface. However, coming 
Open access e-Journal

Earth Science India, eISSN: $0974-8350$

Vol. 8 (II), April, 2015, pp. 32-49

http://www.earthscienceindia.info/

nearer to the main channel the contours are closely intacted though the relief is very subtle. Thus the contours here display an incised river valley system along the main channel.

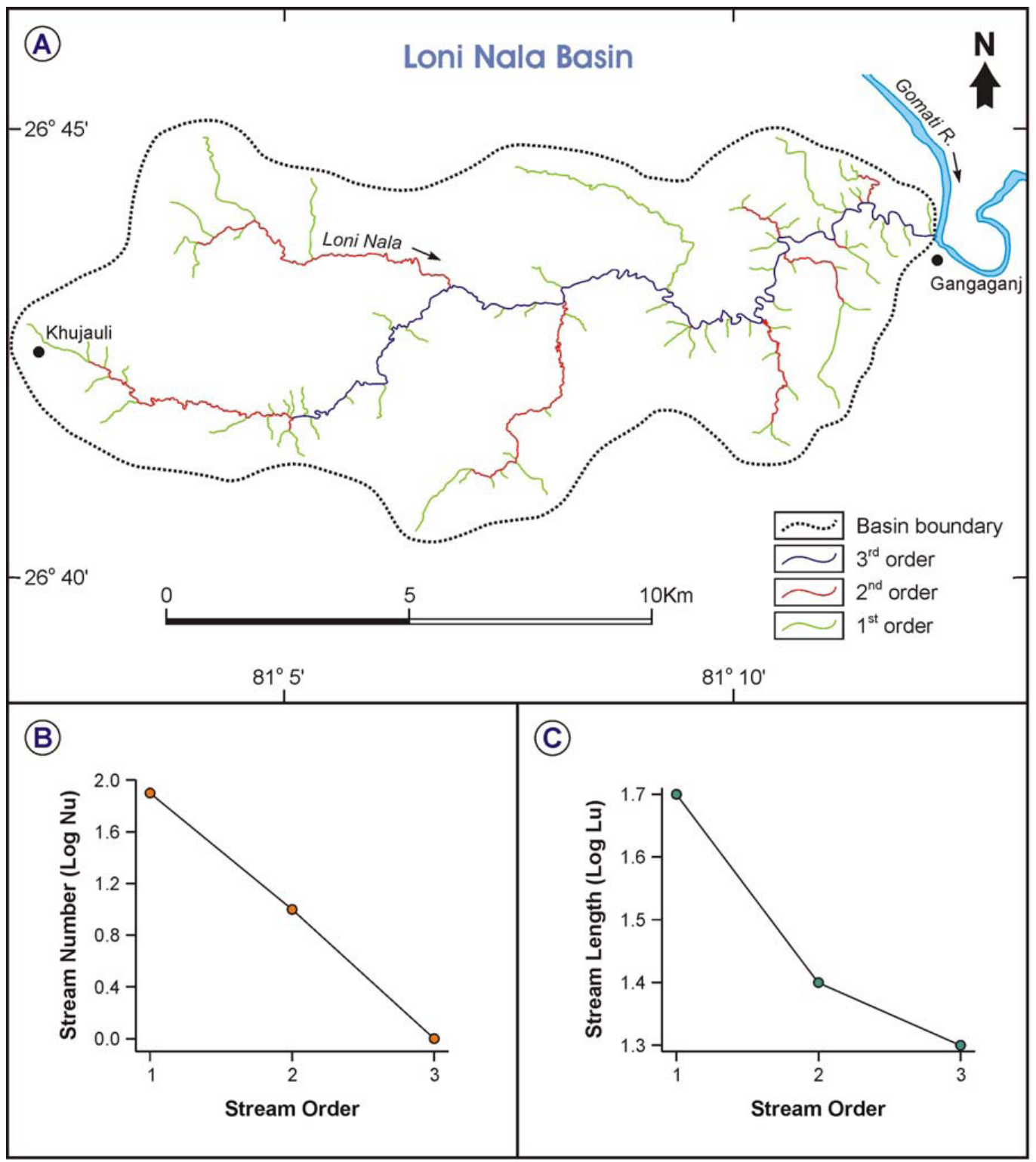

Fig. 2: The Loni Nala Basin: (A) Drainage map; (B) geometric relationship between log values of stream number (Nu) and stream order; (C) geometric relationship between log values of stream length (Lu) and stream order (after Thakur, 2007). 


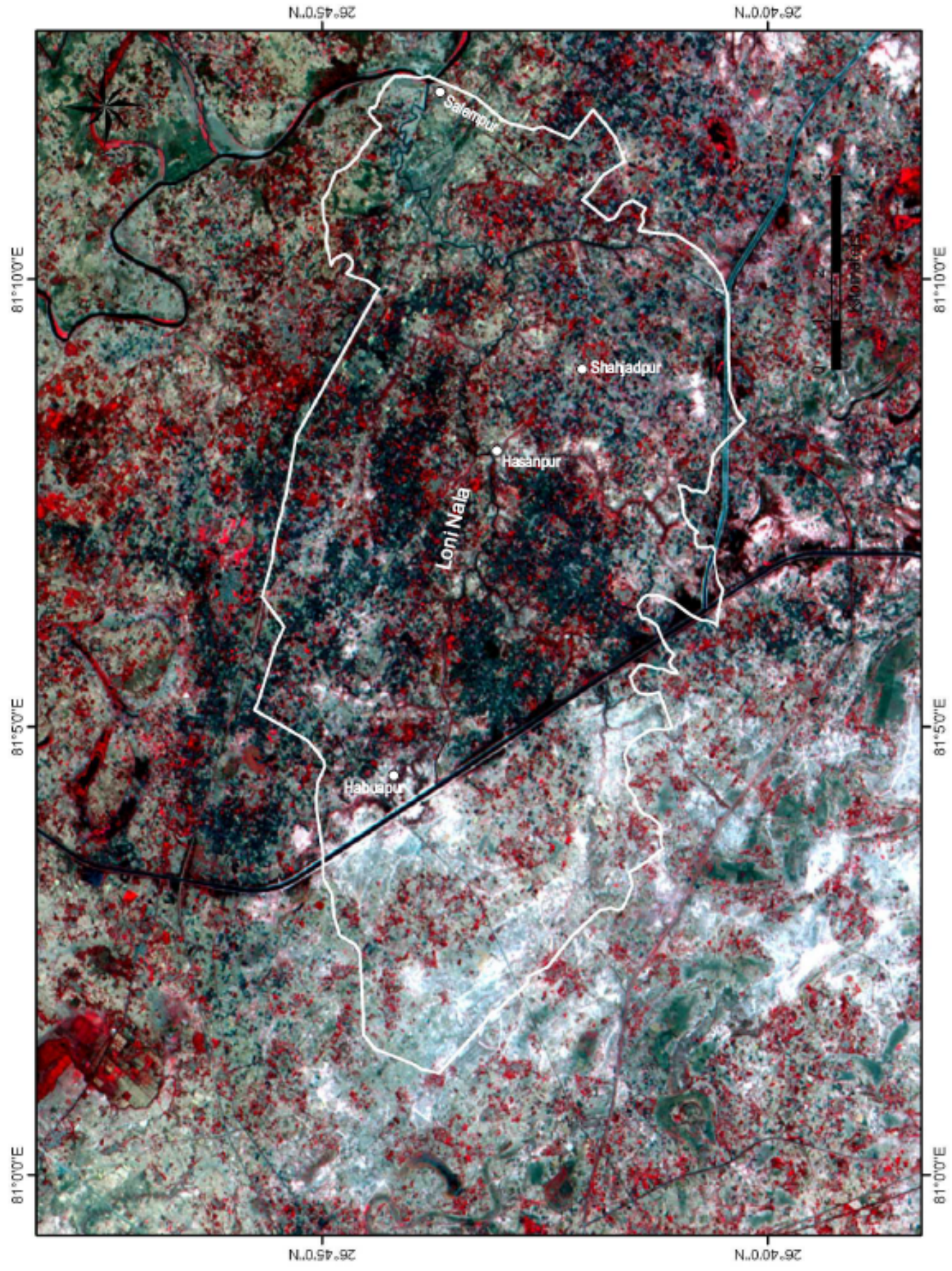

Fig. 3: ETM+ Satellite imagery of Gomati Basin showing basin boundary of Loni Nala. 
Open access e-Journal

Earth Science India, eISSN: $0974-8350$

Vol. 8 (II), April, 2015, pp. 32-49

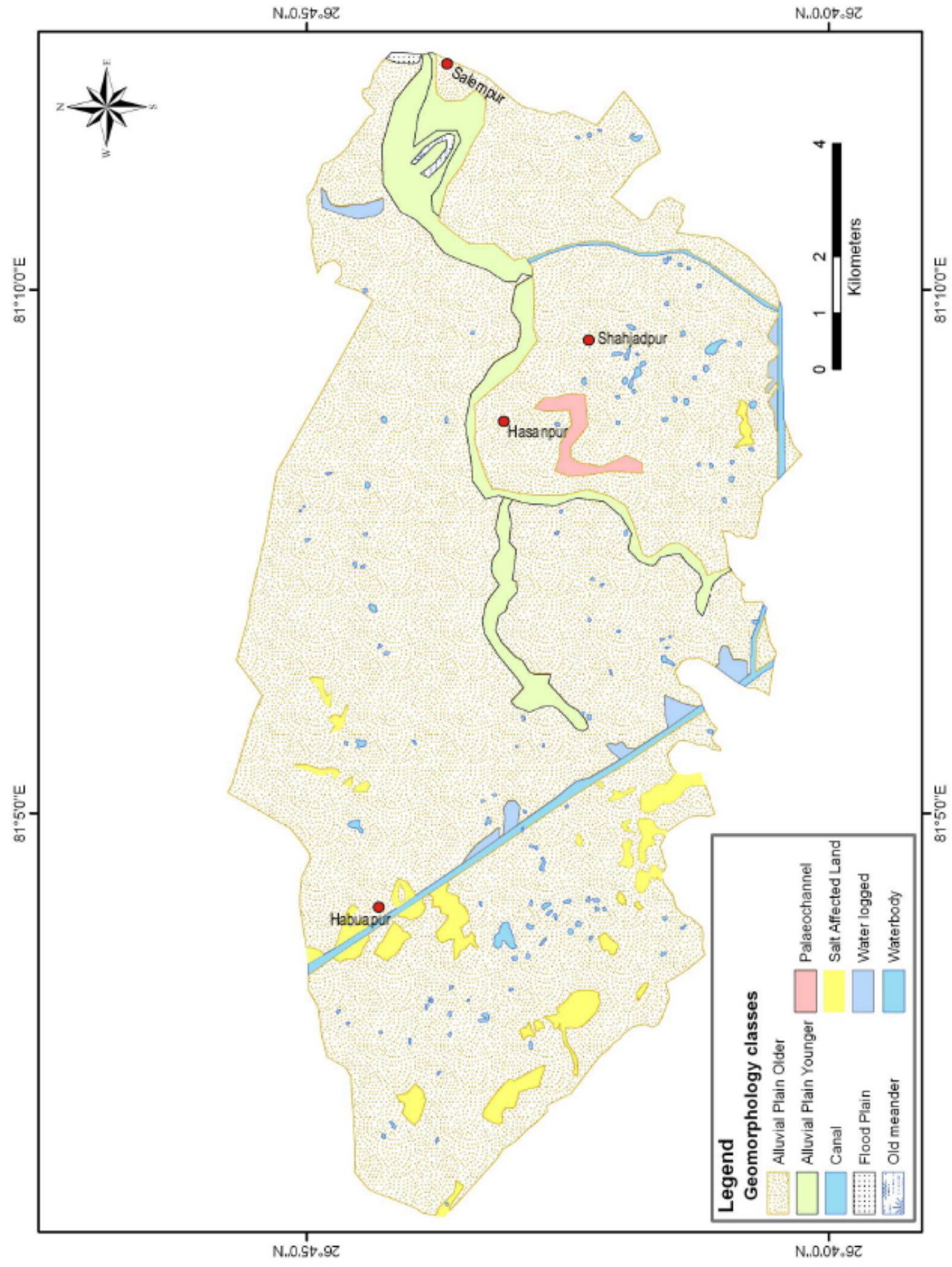

Fig. 4: Geomorphological map of Loni Nala basin, Gomati River. 


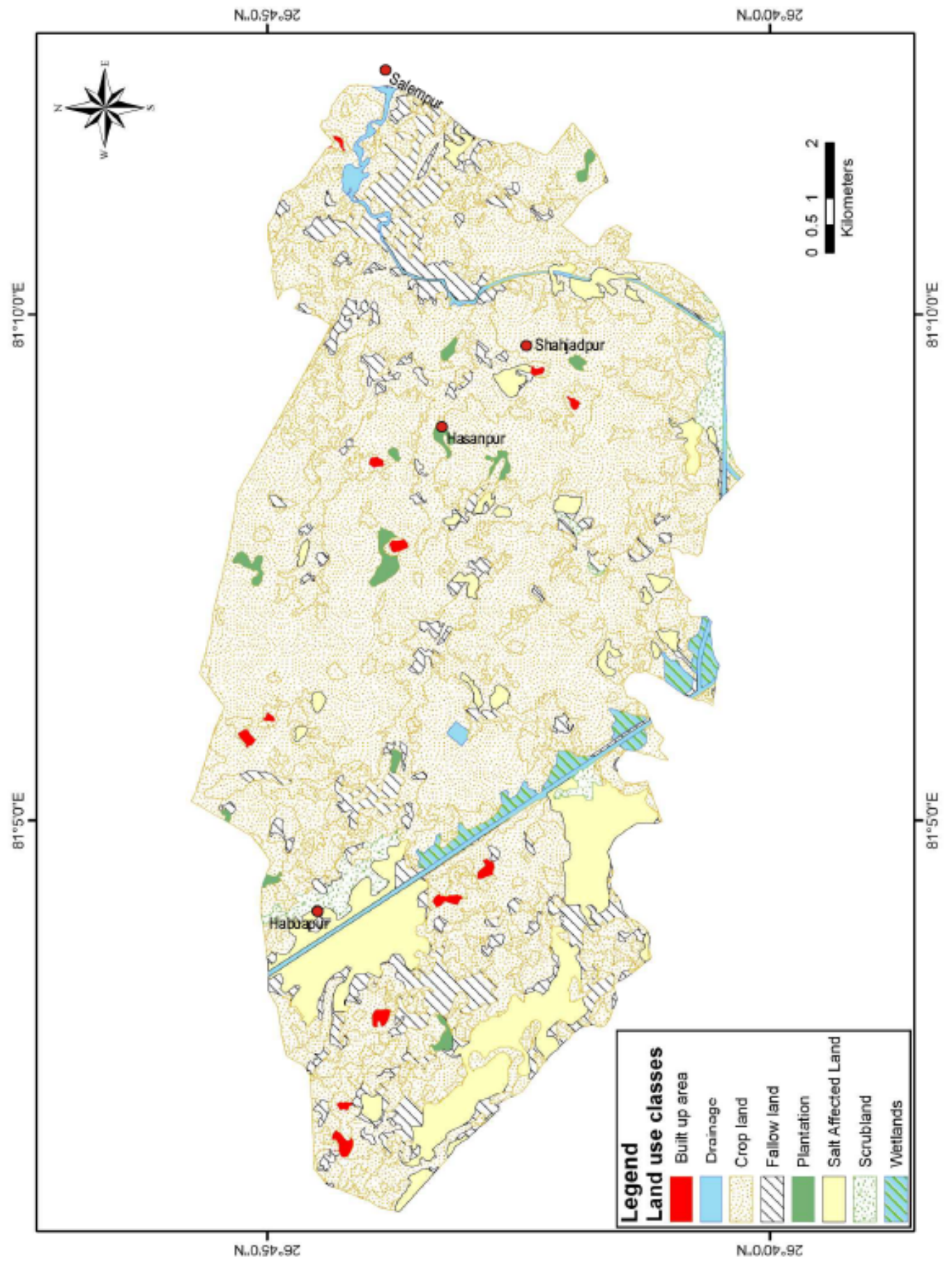

Fig 5: Land use/ Land cover map of Loni Nala basin, Gomati River. 
Open access e-Journal

Earth Science India, eISSN: $0974-8350$

Vol. 8 (II), April, 2015, pp. 32-49

http://www.earthscienceindia.info/

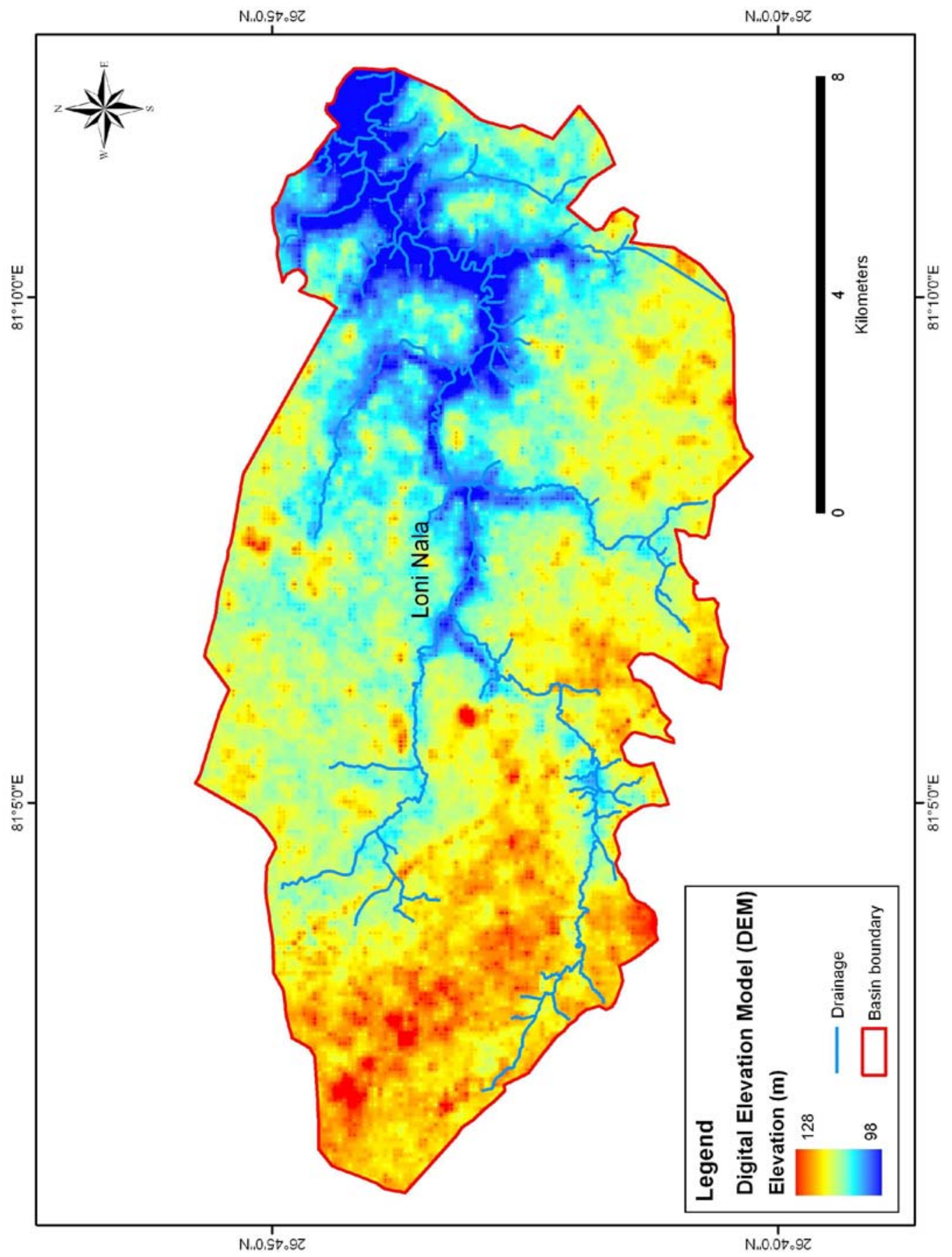

Fig. 6: Digital Elevation Model (DEM) of Loni Nala basin, Gomati River 


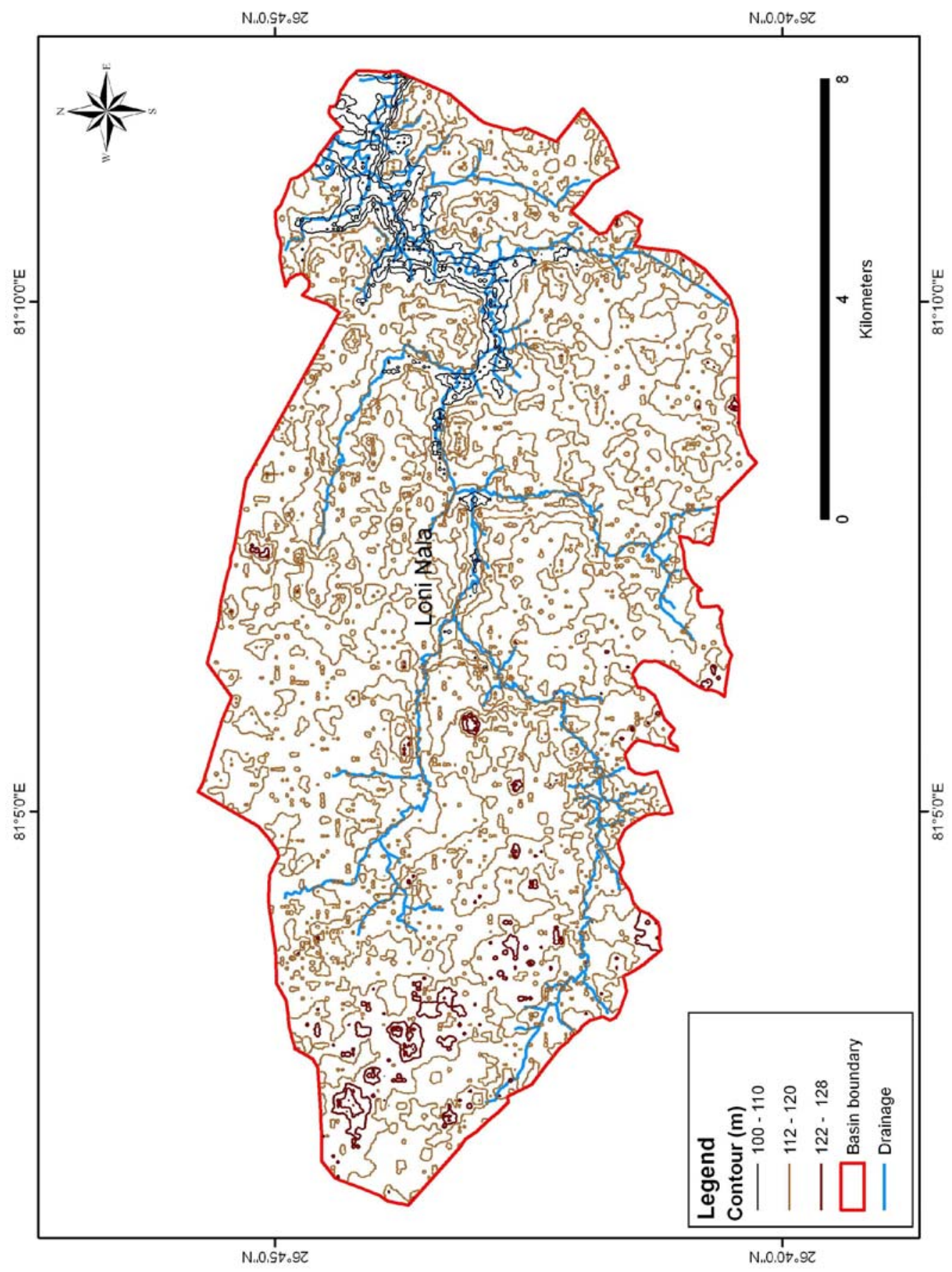

Fig. 7: Contour map of Loni Nala basin, Gomati River. 
Open access e-Journal

Earth Science India, eISSN: $0974-8350$

Vol. 8 (II), April, 2015, pp. 32-49

http://www.earthscienceindia.info/

\section{Conclusions}

From the present study of the Loni Nala, Gomati basin, following conclusions are drawn:

1. The morphometric evidences indicate that though the basin is in mature stage but mostly the drainages are somewhat structurally controlled.

2. The geomorphologic setup of the basin shows dominance of $T_{2}$ and $T_{1}$ surfaces giving impedance to high infiltration rate, low surface runoff and gentle relief.

3. The analysis and orientation of palaeo-channel and old meanders with present active channel are not analogous which also indicate role of tectonics in the basin development.

4. The land use data indicate highly productive areas which are better suited for recharge activities rather than concretization.

5. The elevation model and contour mapping gives evidences of river valley incision in the geo-environmental setup of Loni Nala section.

Acknowledgements: The authors are thankful to the Head, Department of Geography, University of Lucknow for permitting the publication of the paper. They would also like to acknowledge Dr. Alok Thakur, Senior Geologist, Institute of Reservoir Studies, ONGC, Ahmedabad for helping with valuable suggestions and discussions. The authors sincerely thanks Prof. Sunil Bajpai, Director, BSIP for providing basic infrastructural facility.

\section{References}

Agarwal, K.K., Singh, I.B., Sharma, M. and Sharma, S. (2002) Extensional tectonic activity in the cratonward parts (peripheral bulge) of the Ganga Plain foreland basin, India. International Journal of Earth Science, v. 91, pp. 897-905.

Awasthi, A. and Singh, D.S. (2011) Shallow subsurface facies of Chhoti Gandak River Basin, Ganga Plain, India. In: D.S. Singh and N.L. Chhabra (Eds.), Geological Processes and Climate Change. Macmillan Publishers India Ltd. pp. 223-234.

Das Gupta, S. P. (1975) The Upper Gangetic Flood Plain: A regional survey. National Atlas Organization Monograph, Calcutta. pp. 194.

Geddes, A. (1960) The alluvial morphology of the Indo-Gangetic plain: Its mapping and geographic significance. Trans. Inst. British Geographer. v. 28, pp. 253-276.

Grade, R. J. (2006) River Morphology. New Age International (P) Limited, Publishers (formerly Wiley Eastern Limited). 479 p.

Horton, R.E. (1945) Erosional development of streams and their drainage basin, Hydrological approach to quantitative morphology. Geological Society of America Bulletin, v. 56, pp. 275-370.

Kale, V. S. and Gupta, A. (2001) Introduction to geomorphology (Kolkata: Orient Longman).

Kumar, G., Khanna, P.C. and Prasad, S. (1996) Sequence stratigraphy of the foredeep and evolution of IndoGangetic plain, Uttar Pradesh. Proceedings of Symposium on NW Himalaya and Foredeep. Geological Society of India, v. 21, pp. 173-207.

Mesa, L. M. (2006) Morphometric analysis of a subtropical Andean basin (Tucumam, Argentina). Environmental Geology, v. 50(8), pp.1235-1242.

Misra, M. N., Srivastava, R.N., Upadhyaya, M.C. and Srivastava, M.P. (1994) Quaternary geology and morphotectonic evolution of the Lower Sindh Basin, Marginal Gangetic Plain, M.P. and U.P. Journal of the Geological Society of India, v. 43, pp. 677-684. 
Mohindra, R. and Parkash, B. (1994) Geomorphology and neotectonic activity of the Gandak megafan and adjoining areas, middle Gangetic Plains. Journal of the Geological Society of India, v. 43, pp. 149-157.

Mohindra, R., Parkash, B. and Prasad, J. (1992) Historical geomorphology and pedology of the Gandak Megafan, Middle Gangetic Plains, India. Earth Surface Processes and Landforms, v. 17, pp. 643-662.

Mukherji, A.B. (1963) Alluvial morphology of the upper Ganga-Yamuna doab. The Deccan Geographer, v. 2, pp. 1-36.

Oldham, R.D. (1917) The structure of Himalayas and the Gangetic Plain as elucidated by geodetic observations in India. Memoir Geological Society of India, v. 42, pp. 1-153.

Parkash, B., Kumar, S., Rao, M. S., Giri, S.C., Kumar, S.C., Gupta, S. and Srivastava, P. (2000) Holocene tectonic movements and stress fields in the western Gangetic Plain. Current Science, v. 78, pp. 438449.

Pascoe, R.D. (1917) Early history of Indus-Brahamaputra and Ganges. Quaternary Journal of of the Geological Society, London, v. 76, pp. 136.

Pilgrim, G.E. (1919) Suggestions concerning the history of the drainage of northern India arising out of a study of Siwalik boulder conglomerate. Journal of the Asiatic Society of Bengal, v. 15, pp. 81-99.

Reddy, G.P.O., Maji, A.K. and Gajbhiye, K.S. (2004) Drainage morphometry and its influence on landform characteristics in a basaltic terrain, Central India - a remote sensing and GIS approach. International Journal of Applied Earth Observation and Geoinformation, v. 6, pp. 1-16.

Schumm, S.A. (1963) Sinuosity of alluvial rivers of great plains. Geological Society of America Bulletin, v. 74, pp. 1089-1100.

Singh, I. B. (1996) Geological evolution of Ganga Plain- an overview. Journal of the Palaeontological Society of India, v. 41, pp. 99-137.

Singh, I.B. (1999) Tectonic control on sedimentation in Ganga Plain foreland basin: constrained on Siwalik sedimentation models. In: A.K. Jain and R.M. Manickavasagam (Eds.) Geodynamics of the NW Himalaya. Gondwana Research Group Memoir, v. 6, pp. 247-262.

Singh, I.B. (2001) Proxy records of neotectonics, climate change and anthropogenic activity in the late Quaternary of Ganga Plain. Geological Survey of India Special Publication No. 65(1), XXXIII-L.

Singh, I.B. and Bajpai, V.N. (1989) Significance of syndepositional tectonics in the facies development of the Gangetic Alluvium near Kanpur, Uttar Pradesh. Journal of the Geological Society of India, v. 34, pp. 61-66.

Singh, I.B. and Ghosh, D.K. (1994) Geomorphology and neotectonic features of Indo-Gangetic Plain. In: K.R. Dikshit, V.S. Kale and M.N. Kaul (Eds.) India: Geomorphological diversity, pp. 270-286.

Singh, I.B. and Rastogi, S.P. (1973) Tectonic framework of Gangetic alluvium with special reference to Ganga River in Uttar Pradesh. Current Science, v. 42, pp.305-307.

Singh, I.B. and Rastogi, S.P. (1975) Some less common sedimentary structures from the point bar and natural levee deposits of Gomati River, Uttar Pradesh, India. Geophytology, v. 5, pp. 186-187.

Singh, I.B. (2002) Late Quaternary evolution of Ganga Plain and proxy records of climate change and anthropogenic activity. Pragdhara, v.12 (2001-2002), pp.1-25.

Singh, I.B. (2004) Late Quaternary History of the Ganga Plain. Journal of the Geological Society of India, v.64, pp. 431-454.

Singh, I.B., Ansari, A.A., Chandel, R.S. and Misra, A. (1996) Neotectonic control on drainage system in Gangetic Plain, Uttar Pradesh. Journal of the Geological Society of India, v. 47, pp. 599-609.

Singh, I.B., Ansari, A.A., Chandel, R.S. and Misra, A. (1996) Neotectonic control on drainage system in Gangetic Plain, Uttar Pradesh. Journal of the Geological Society of India, v. 47, pp.599-609.

Sinha, R., Jain, V., Babu, G.P. and Gosh, S. (2005) Geomorphic characterization and diversity of the fluvial systems of the Gangetic Plains. Geomorphology, v. 70, pp. 207-225.

Smith, K.G. (1950) Standards for grading texture of erosional topography. American Journal of Science, v. 248, pp. 655-668.

Sreedevi, P.D., Subrahmanyam, K. and Ahmed, S. (2005) The significance of morphometric analysis for obtaining groundwater potential zones in a structurally controlled terrain. Environmental Geology, v. 47, pp. 412-420. 
Open access e-Journal

Earth Science India, eISSN: 0974 - 8350

Vol. 8 (II), April, 2015, pp. 32-49

http://www.earthscienceindia.info/

Srivastava, P., Parkash, B. and Pal, D.K. (1994) Role of neotectonic activities and climate in development of Holocene geomorphology and soils of Gangetic Plains between Ramganga and Rapti Rivers. Sedimentary Geology, v. 94, pp.129-131.

Srivastava, P., Singh, I.B., Sharma, M. and Singhvi, A.K. (2003) Luminescence chronometry and Late Quaternary geomorphic history of the Ganga Plains, India. Palaeogeography, Paleoclimatology, Palaeoecology, v. 197, pp. 15-41.

Strahler, A.N. (1952) Hypsometric (area-altitude) analysis of erosional topography. Geological Society of America Bulletin, v. 63, pp. 1117-1142.

Strahler, A.N. (1957) Quantitative analysis of watershed geomorphology. Trans. American Geophysical Union, v. 38, pp. 913-920.

Strahler, A.N. (1964) Quantitative geomorphology of drainage basin and channel network. In: V.T. Chow (Ed.), Handbook of applied hydrology. McGraw Hill Book Co., New York. pp. 4-76.

Thakur, A. (2007) Morphology and Basin Characteristics of the Gomati River, the Ganga Plain, India. Unpublished Thesis.

Vandana, M. (2013) Morphometric analysis and watershed prioritisation: a case study of Kabani river basin, Wayanad district, Kerala, India. Indian Journal of Geo-Marine Sciences, v. 42(2), pp. 211-222.

(submitted: 21.01.2015; accepted: 28.04.2015) 